\title{
KEANEKARAGAMAN JENIS IKAN FAMILI CYPRINIDAE DI SUNGAI ARIUNG KECAMATAN PUTUSSIBAU UTARA KABUPATEN KAPUAS HULU
}

\author{
(Speciees Fish Diversity of Cyprinidae Family in Ariung River Putussibau Utara District \\ Kapuas Hulu Regency)
}

\author{
Sy. M. Tarmizi Septian, Hari Prayogo, M. Dirhamsyah \\ Fakultas Kehutanan Universitas Tanjungpura, Jalan Imam Bonjol Pontianak, 78124 \\ E-mail: septiantarmizi058@gmail.com
}

\begin{abstract}
The cyprinidae family is a true freshwater fish that dominant in Indonesian fresh waters and the main in habitant of the most population in several rivers in Kalimantan. One of river that found cyprinidae family is Ariung river in Mendalam Village, North Putussibau District, Kapuas Hulu Regency, West Kalimantan. This study aims to obtain data on the fish diversity of the cyprinidae in Ariung River. The method used in this research is survey method and direct observation in the field. Determination of sampling points with purposive sampling and followed systematically based on environmental conditions. The results showed as many as 5 observation stations found 187 individuals belonging to 15 types, among them are Barbichthys laevis, Barbodes schwanenfeldii, Cyclocheilichtys apogon, Hampala macrolepidota, Labiobarbus ocellatus, Osteochilus hasselti, Osteochilus kappenii, Osteochilus microcephalus, Osteochilus pleurotaenia, Osteochilus waandersii, Puntioplites bulu, Rasbora caudimaculata, Rasbora sp, Thynnichthys polylepis dan Thynnichthys thynnoides. Based on the results of data analysis, the dominant index of fish in the Ariung river shows low dominance. Values (C) from the five observation stations ranged from 0.135 - 0.284. The index of fish species diversity in the Ariung river shows moderate species diversity. Diversity index $\left(H{ }^{\prime}\right)$ values for the five stations ranged from $1.322-2.130$. Evenness index $(E)$ values at the five stations are at $0.912-0.953$ and a wealth index $(R)$ at the five stations has a high wealth of $R>4$.
\end{abstract}

Keywords: Ariung Rivers, Cyprinidae Family, Fish Diversity

\section{PENDAHULUAN}

Kalimantan merupakan salah satu pulau terbesar di Indonesia. Kondisi geografis yang memiliki banyak bukit di bagian hulu mengakibatkan Kalimantan memiliki banyak aliran sungai. Sungai mempunyai potensi dan peranan penting bagi kelangsungan aktivitas seluruh makhluk hidup. Salah satu perairan air tawar yang ada di pedalaman Kalimantan yaitu Sungai Ariung yang merupakan anak sungai mendalam yang berada di Kabupaten
Kapuas Hulu Kalimantan Barat. Sungai ini merupakan habitat perairan tawar yang penting bagi kehidupan fauna, salah satunya adalah ikan.

Ikan merupakan penghuni utama pada ekosistem akuatik yang tersebar pada perairan tawar seperti, sungai, danau dan rawa serta perairan payau dan perairan laut (Augusta, 2015). Ikan memiliki peranan penting bagi ekosistem dan lingkungan dimana dapat dijadikan bioindikator terhadap kualitas 
suatu badan perairan ( Rahman et al., 2012). Masyarakat yang hidup di bantaran Sungai Ariung juga mengandalkan ikan sebagai mata pencaharian, selain dikonsumsi sendiri juga dijual untuk memenuhi kebutuhan yang lain. Ikan yang banyak dimanfaatkan oleh masyarakat baik sebagai ikan hias maupun konsumsi adalah ikan famili cyprinidae.

Famili cyprinidae merupakan ikan air tawar sejati yang paling banyak mendominasi perairan. Hal yang demikian merupakan kondisi yang cukup umum terjadi di perairan Indonesia khususnya di Jawa, Sumatera, dan Kalimantan. Menurut penelitian Aryanti (2007), jenis ikan yang paling banyak mendominasi di kawasan Sub DAS Labian adalah ikan yang berasal dari famili cyprinidae. Kottelat et al., (1993) menyebutkan bahwa ikan famili cyprinidae merupakan penghuni utama yang paling banyak populasinya di beberapa sungai di Kalimantan. Rachmatika dan Haryono (1996), famili cyprinidae merupakan ikan yang mendominasi di daerah kawasan Taman Nasional Betung Kerihun di Perbatasan Kalimantan Barat dan Malaysia. Hal yang sama juga dilaporkan di Aliran Riam Banangar Kabupaten Landak (Adis, 2017) dan di Sungai Dong Sandar dan Sungai Rempangi Kabupaten Ketapang, Kalimantan Barat (Ongki, 2018).

Berdasarkan penelitian terdahulu penting dilakukannya penelitian tentang keanekaragaman jenis ikan family cyprinidae guna memperkaya data keanekaragaman hayati di Sungai Ariung. Penelitian tentang keanekaragaman jenis ikan famili cyprinidae di Sungai Ariung merupakan sebuah upaya untuk menunjang kepentingan pelestarian jenis ikan terutama ikan famili cyprinidae dan sebagai salah satu informasi awal pertimbangan dalam kebijakan pengelolaan kawasan karena masih terbatasnya database mengenai jenis ikan yang terdapat di Sungai Ariung. Tujuan penelitian ini untuk mendapatkan data keanekaragaman jenis ikan famili cyprinidae yang ada di Sungai Ariung Kecamatan Putussibau Utara Kabupaten Kapuas Hulu.

\section{METODE PENELITIAN}

Penelitian ini dilaksanakan di Sungai Ariung Desa Ariung Mendalam Kecamatan Putussibau Utara Kabupaten Kapuas Hulu, dimulai tanggal 20 April sampai dengan tanggal 20 Mei 2019.

Alat yang digunakan diantaranya jala tebar dengan mata jaring $2 \mathrm{~cm}$, pukat dengan mata jaring $2 \mathrm{~cm}, 3 \mathrm{~cm}$, dan $4 \mathrm{~cm}$, seluak dari botol minuman, bubu dari bambu dan rotan, temilar dari rotan, sauk dengan mata jaring $1 \mathrm{~cm}$, sampan, GPS, penggaris, kaliper, buku identifikasi, timbangan, meteran, kamera, tallysheet. Bahan yang digunakan untuk umpan ikan yaitu ampas padi dan objek penelitian yaitu sampel ikan yang tertangkap, selanjutnya di identifikasi menggunakan buku identifikasi ikan dari Kottelat et al., (1993).

Penentuan titik sampling dilakukan dengan Purposive Sampling dan diikuti 
secara Sistematik (Effendie,1979) berdasarkan pada kondisi lingkungan. Lokasi penelitian terdapat 5 (lima) stasiun dengan panjang 50 meter dan interval antar stasiun minimal 100 meter. Setiap stasiun dilakukan pengambilan sampel sebanyak 3 (tiga) kali pengulangan.

\section{Pengumpulan Data}

Pengambilan sampel ikan dilakukan dengan metode hasil tangkap per unit usaha (Rachmatika dan Haryono, 1996) yaitu dengan menggunakan alat tangkap jala dengan 10 kali tebaran setiap stasiun, dengan 1 utas pukat dengan mata jaring $2 \mathrm{~cm}, 3$ $\mathrm{cm}$, dan $4 \mathrm{~cm}$ setiap stasiun, 3 buah seluak satu di tengah dan dua di tepian sungai setiap stasiun, 1 buah bubu di tepian sungai setiap stasiun dan 1 buah temilar di pasang tepian sungai setiap stasiun, menebar jala terlebih dahulu menghamburkan umpan supaya menghasilkan jumlah tangkap yang banyak. Pemasangan seluak, bubu, dan temilar dilakukan sehari sebelum pengambilan sampel di stasiun. Sampel ikan family cyprinidae yang tertangkap pada setiap lokasi dicatat jenis dan jumlahnya, ukur panjang total dan panjang standar, ditimbang beratnya, dan setiap jenis ikan family cyprinidae dibuat dokumentasinya.

\section{Analisis Data}

Data ikan famili cyprinidae yang ditemukan dianalisis menggunakan indeks Dominansi (C), indeks keanekaragaman jenis (H'), indeks kemerataan jenis (E) dan indeks kekayaan jenis (R).

\section{HASIL DAN PEMBAHASAN}

Berdasarkan hasil penelitian jumlah jenis ikan famili cyprinidae yang ditemukan di Sungai Ariung sebanyak 15 jenis. Jenis ikan famili cyprinidae yang didapatkan di lokasi penelitian cukup beragam serta bervariasi mulai dari bentuk dan ukuran (tabel 1).

Tabel 1. Jenis-jenis Ikan Famili Cyprinidae yang ditemukan di Sungai Ariung (Fish Species Of Cyprinidae Family Found In The Ariung River)

\begin{tabular}{lll}
\hline No & Nama Daerah & Nama Ilmiah \\
\hline 1. & Kungkum & Barbichthys laevis \\
2. & Tengadak & Barbodes schwanenfeldii \\
3. & Buin & Cyclocheilichtys apogon \\
4. & Langkung & Hampala macrolepidota \\
5. & Bauk Gulung & Oabiobarbus ocellatus \\
6. & Palau & Osteochilus hasselti \\
7. & Kelabau Padi & Osteochilus microcephalus \\
8. & Bantak & Osteochilus pleurotaenia \\
9. & Ikan Batu & Osteochilus waandersii \\
10. & Umpan & Puntioplites bulu \\
11. & Tengalan & Rasbora caudimaculata \\
12. & Sarai & Rasbora sp. \\
13. & Seluang & Thynnichthys polylepis \\
14. & Bauk Pipih & Thynnichthys thynnoides \\
15. & Entukan & \\
\hline
\end{tabular}


Sungai Ariung merupakan anak Sungai Mendalam yang terletak di bagian Utara Desa Ariung Mendalam yang panjangnya dari Sambus sampai Nanga Danau yaitu 4,05 Km. Kondisi habitat di sepanjang Sungai Ariung dijumpai adanya permukiman, ladang, dan hutan sekunder. Kondisi stasiun I di sekitar sungai terdapat hutan sekunder yang di dominasi pohon sengon. Lebar sungai mencapai 20 meter dengan kedalaman air 2 meter dan dasar sungai tanah berpasir. Kondisi stasiun II berada di tikungan sungai yang berarus sedang dan di sekitarnya terdapat vegetasi pinggiran dari famili Graminae. Substrat pada stasiun ini tanah berpasir dengan lebar sungai 15 meter dan kedalaman mencapai 1 meter. Stasiun
III kondisi di sekitar sungai terdapat ladang kratom. Substrat tanah berpasir, lebar sungai 20 meter dengan kedalaman air mencapai 2 meter dan berarus deras. Kondisi stasiun IV berada dekat permukiman masyarakat suku Dayak Taman yang disekitar stasiun pengamatan terdapat sarana kegiatan manusia yaitu Mandi, Cuci, Kakus (MCK). Lebar sungai di stasiun ini mencapai 20 meter dengan kedalaman air mencapai 2 meter berarus deras, sedangkan kondisi stasiun V berada di bawah jembatan penyebrangan Desa Ariung Mendalam.Kedalaman air mencapai 2 meter dengan lebar sungai 25 meter berarus deras dan kondisi di dasar sungai bersubstrat tanah berpasir.

Tabel 2. Jenis dan jumlah ikan famili cyprinidae yang ditemukan pada setiap stasiun (Fish Species and Number of Cyprinidae Family Found at Each Station)

\begin{tabular}{|c|c|c|c|c|c|c|c|}
\hline \multirow[t]{2}{*}{ No } & \multirow{2}{*}{$\begin{array}{l}\text { Nama } \\
\text { Daerah }\end{array}$} & \multirow{2}{*}{$\begin{array}{l}\text { Nama } \\
\text { Ilmiah }\end{array}$} & \multicolumn{5}{|c|}{ Stasiun } \\
\hline & & & 1 & 2 & 3 & 4 & 5 \\
\hline 1. & Kungkum & Barbodes laevis & 2 & 4 & 3 & - & - \\
\hline 2. & Tengadak & Barbodes schwanenfeldii & 2 & - & 3 & - & - \\
\hline 3. & Buin & Cyclocheilichtys apogon & 3 & - & 1 & - & - \\
\hline 4. & Langkung & Hampala macrolepidota & - & 2 & - & - & - \\
\hline 5. & Bauk Gulung & Labiobarbus ocellatus & 8 & 14 & 7 & 16 & 7 \\
\hline 6. & Palau & Osteochilus hasselti & - & - & - & - & 2 \\
\hline 7. & Kelabau Padi & Osteochilus kappenii & - & - & - & - & 1 \\
\hline 8. & Bantak & Osteochilus microcephalus & 9 & 5 & 5 & 9 & - \\
\hline 9. & Ikan Batu & Osteochilus pleurotaenia & 4 & - & 6 & - & 6 \\
\hline 10. & Umpan & Osteochilus waandersii & - & - & 1 & - & 1 \\
\hline 11. & Tengalan & Puntioplites bulu & - & - & - & - & 2 \\
\hline 12. & Sarai & Rasbora caudimaculata & 3 & 2 & 3 & - & 5 \\
\hline 13. & Seluang & Rasbora sp. & 9 & 6 & 2 & 9 & 5 \\
\hline 14. & Bauk Pipih & Thynnichthys polylepis & 3 & 2 & - & 6 & 7 \\
\hline 15. & Entukan & Thynnichthys thynnoides & - & - & 2 & - & - \\
\hline \multicolumn{3}{|c|}{ Jumlah Jenis } & 43 & 35 & 33 & 40 & 36 \\
\hline
\end{tabular}

Hasil penelitian di Sungai Ariung menunjukkan adanya persamaan dan perbedaan jenis ikan yang berhasil ditangkap pada kelima stasiun. Stasiun V didapatkan sembilan jenis ikan famili cyprinidae diantaranya didapatkan jenis 
Osteochilus kappenii dan Puntioplites bulu. Kondisi perairan pada stasiun ini di sekitar sungai terdapat banyak ranting kayu besar yang tenggelam. Stasiun V sedikit lebih lebar dari stasiun lainnya, kedalaman air mencapai 2 meter dengan arus deras. Berbeda dengan stasiun V pada stasiun IV hanya mendapatkan empat jenis ikan diantaranya Labiobarbus ocellatus, Osteochilus microcephalus, Rasbora sp dan Thynnichthys polylepis. Jenis ikan yang sedikit didapat dikarenakan adanya kegiatan manusia disekitar stasiun pengamatan yaitu Mandi Cuci Kakus (MCK).

Kondisi lingkungan yang hampir sama ditunjukkan pada stasiun I, II dan III. Hal ini terlihat dari bentuk maupun ukuran tubuh ikan yang didapatkan pada ketiga stasiun, jenis yang dijumpai diantaranya Barbichthys laevis, Barbodes schwanenfeldii, Cyclocheilichtys apogon, Hampala macrolepidota, Labiobarbus ocellatus, Osteochilus microcephalus, Osteochilus pleurotaenia, Rasbora caudimaculata, Rasbora sp dan Thynnichthys polylepis. Kondisi lingkungan pada ketiga stasiun ini terdapat vegetasi pinggiran yang mendominasi dari famili Graminae, di sekitar sungai sebagian dikelilingi hutan dan perladangan, sehingga tersedianya sumber pakan bagi ikan, baik dari daun tumbuhan, biji - bijian, dan buah - buhan yang jatuh dan hanyut di dalam air yang menggenang dengan arus yang deras. Kondisi lingkungan yang hampir sama umumnya memberikan pengaruh yang hampir sama pada komunitas yang hidup di dalamnya (Rahim, 2002). Secara umum air Sungai Ariung berwarna coklat dengan dasar tanah berpasir dan berarus deras, dengan kedalaman mencapai \pm 2 meter dan sepanjang sungai dikelilingi hutan. Menurut MacKinnon et al., (2000) terdapat korelasi yang nyata antara lebar dan kedalaman sungai terhadap peningkatan keragaman spesies ikan. Tipe aliran sungai yang terbuka memberi peluang untuk mendapatkan masukkan air dari perairan lainnya. Total yang didapatkan pada kelima stasiun sebanyak 187 individu, ikan yang paling banyak ditemukan pada lima stasiun yakni Labiobarbus ocellatus dengan total 52 individu diikuti oleh Rasbora sp sebanyak 31 individu dan Osteochilus microcephalus sebanyak 28 individu. Secara umum ikan family cyprinidae yang terdapat pada stasiun I, II, dan III dijumpai jenis yang sama. 
Tabel 3. Indeks dominan, indeks keanekaragaman jenis, indeks kemerataan jenis, dan indeks kekayaan jenis ikan famili cyprinidae yang ditemukan pada setiap stasiun di Sungai Ariung (Dominand Index, Diversity Index, Evenness Index, and Richness Index Fish Species of Cyprinidae family Found at Each Station In Ariung River)

\begin{tabular}{ccccc}
\hline & \multicolumn{4}{c}{ Nilai Indeks } \\
\cline { 2 - 5 } Stasiun & $\mathbf{C}$ & H' & $\mathbf{E}$ & $\mathbf{R}$ \\
\hline 1 & 0,150 & 2,031 & 0,924 & 8,734 \\
2 & 0,233 & 1,685 & 0,866 & 6,719 \\
3 & 0,135 & 2,130 & 0,925 & 9,714 \\
4 & 0,284 & 1,322 & 0,953 & 3,729 \\
5 & 0,150 & 2,004 & 0,912 & 8,720 \\
\hline
\end{tabular}

Berdasarkan hasil yang diperoleh pada tabel 6, nilai indeks dominan (C) berkisar antara $0,135-0,284$.Nilai (C) tertinggi terjadi pada stasiun IV dengan nilai sebesar 0,284. Indeks dominan (C) merupakan parameter yang digunakan dalam suatu komunitas untuk menyatakan tingkat terpusatnya dominansi suatu spesies. Menurut Ferianita (2007), kisaran nilai indeks dominan adalah $0-1$. Nilai $(C)=0$ berarti tidak terdapat jenis yang mendominasi jenis lainnya dan $(\mathrm{C})=1$ berarti terdapat jenis yang mendominasi jenis lainnya. Kondisi ini menunjukan bahwa dari kelima stasiun pengamatan tidak ada penguasaan suatu jenis terhadap jenis yang lainnya dalam suatu komunitas, karena nilai indeks dominan yang didapat tidak ada yang mendekati 1. Jenis ikan yang didapatkan pada kelima stasiun beragam jenis dan tidak terpusat pada satu jenis disetiap stasiun pengamatan.

Indeks keanekaragaman jenis ikan di Sungai Ariung menunjukkan keanekaragaman jenis yang sedang. Nilai indeks keanekaragaman (H') pada kelima stasiun berkisar antara 1,322 2,130. Kriteria indeks keanekaragaman jenis menurut Ferianita (2007), yaitu jika nilai $\mathrm{H}^{\prime}<1$ berarti keanekaragaman jenis rendah, jika nilai $1<\mathrm{H}^{\prime}<3$ menunjukkan keanekaragaman jenis sedang dan jika nilai $\mathrm{H}^{\prime}>3$ berarti menunjukkan keanekaragaman jenis yang tinggi. Nilai H' pada stasiun III menunjukkan keanekaragaman jenis yang tergolong tinggi dikarenakan jumlah individu yang ditemukan lebih banyak dan jenis ikan yang didapatkan juga lebih beragam dibandingkan dengan stasiun pengamatan yang lain. Kondisi habitat juga sangat mendukung sebagai tempat hidup ikan. Seperti tercantum dalam tulisan Indriyani (2007), Heddy dan Kurniati (1994) menjelaskan bahwa di dalam suatu ekosistem sederhana dengan keanekaragaman jenis yang rendah seringkali memberikan dominansi yang kuat, sebaliknya keanekaragaman jenis yang tinggi seringkali menunjukkan dominansi yang rendah.

Indeks Kemerataan (Indeks of Evennes) berfungsi untuk mengetahui 
kemerataan setiap jenis dalam setiap komunitas yang dijumpai. Semakin kecil nilai (E) atau mendekati nol, maka semakin tidak merata penyebaran organisme dalam komunitas tersebut yang didominasi oleh jenis tertentu dan sebaliknya semakin besar nilai (E) atau mendekati satu, maka organisme dalam komunitas akan menyebar secara merata (Krebs, 1989). Berdasarkan hasil analisis pada tabel 6, nilai indeks kemerataan jenis terendah terdapat pada stasiun II yang berada pada nilai 0,866 sedangkan nilai indeks kemerataan pada stasiun I, III, IV dan V berada pada nilai $0,912-0,953$ dengan demikian keempat stasiun tersebut mempunyai kemerataan populasi yang tinggi dan komunitasnya stabil, karena nilai (E) mendekati 1. Hal ini dikarenakan kondisi habitat keempat stasiun cukup lebar dengan kedalaman mencapai 2 meter dan berarus deras sehingga relatif aman bagi tempat hidup ikan. Nilai indeks kemerataan yang tinggi memperlihatkan bahwa jenis - jenis ikan yang tertangkap di setiap stasiun menunjukkan bahwa ikan terdistribusi secara merata (Kawaroe, 2001).

$$
\text { Indeks Kekayaan jenis }
$$
merupakan ukuran keanekaragaman hayati yang paling sederhana karena hanya memperhitungkan perbedaan jumlah spesies pada suatu areal tertentu.Indeks kekayaan berfungsi untuk mengetahui kekayaan jenis setiap spesies dalam setiap komunitas yang dijumpai (Margalef, 1958). Berdasarkan hasil perhitungan indeks kekayaan pada tabel 6 pada stasiun I, 11, III dan V didapatkan kekayaan yang tinggi $\mathrm{R}>4$, sedangkan pada stasiun IV nilai indeks kekayaan jenis sedang dengan $(\mathrm{R})=$ 3,729. Kriteria indeks kekayaan jenis menurut Margalef (1958), yaitu jika nilai $\mathrm{R}<2,5$ berarti kekayaan jenis rendah, jika nilai $2,5>\mathrm{R}>4$ menunjukkan kekayaan jenis sedang dan jika nilai $\mathrm{R}>4$ berarti menunjukkan kekayaan jenis yang tinggi.

\section{Kesimpulan}

Jenis ikan famili cyprinidae yang ditemukan di lokasiSungai AriungDesa Ariung Mendalam Kecamatan Putussibau Utara Kabupaten Kapuas Hulu adalah sebanyak 187 individu tergolong dalam 15 jenis.Berdasarkan hasil analisisdata, Indeks dominan (C) ikan di sungai Ariung menunjukkan dominansi yang rendah. Nilai (C) dari kelima stasiun pengamatan berkisar antara $0,135 \quad-\quad 0,284$ Indeks keanekaragaman jenis ikan di Sungai Ariung menunjukkan keanekaragaman jenis yang sedang. Nilai indeks keanekaragaman (H') pada kelima stasiun berkisar antara 1,322 - 2,130. Nilai indeks kemerataan (E) pada kelima stasiun berada pada nilai 0,912 0,953 dan Nilai Indeks kekayaan (R) pada kelima stasiun didapatkan kekayaan yang tinggi $\mathrm{R}>4$.

\section{Saran}

1. Perlu dipertahankan pola penangkapan ikan dengan alat tangkap yang standar untuk menjaga kepunahan beberapa jenis ikan.

2. Mengingat akan pentingnya data dan informasi mengenai berbagai potensi 
sumber daya alam di kawasan Sungai Ariung khususnya keanekaragaman jenis ikan, diperlukan suatu penelitian lanjutan yang berkesinambungan.

\section{Ucapan Terima Kasih}

Ucapan terima kasih penulis sampaikan kepada Kepala Desa Ariung Mendalam yang selalu mendampingi selama kegiatan penelitian sehingga penelitian ini dapat terlaksana. Penulis juga mengucapkan terima kasih kepada berbagai pihak yang terlibat dalam penelitian.

\section{DAFTAR PUSTAKA}

Adrim M dan Fahmi. 2010. Panduan Penelitian untuk Ikan Laut. Pusat Penelitian Oseanografi-LIPI. Jakarta.

Adis MA, TR Setyawati dan HY Ari. 2017. Keragaman Jenis Ikan Arus Deras di Aliran Riam Banangar Kabupaten Landak. Jurnal Protobiont 3 (2) : 209 - 2017.

Asriyana, MF Rahardjo, S Sukimin, DF Lumban Batu dan ES Kartamihardja. 2009. Keanekaragaman Ikan di Perairan Teluk Kendari Sulawesi Tenggara. Jurnal Iktioligi Indonesia 9 (2) : 97 - 112.

Augusta TS. 2015. Inventarisasi Ikan dan Kondisi Habitat di Danau Hanjalutung Kalimantan Tengah. Jurnal Ilmu Hewani Tropika 4 (2) : $45-48$.

Dian S dan Zico FR. 2018.

Keanekaragaman Ikan di Sungai Kelingi Kota Lubuklingau. Jurnal Biota 4 (1) : 1 - 6 .

Effendie MI. 1979. Metoda Biologi Perikanan. Yayasan Dewi Sri. Bogor.
Faradiana R, A Budiharjo dan S Sugiyarto. 2018. Keragaman Ikan di Waduk Mulur Sukoharjo Jawa Tengah Indonesia. Jurnal Depik 7 (2) : $151-163$.

Ferianita FM. 2007. Metode Sampling Bioekologi. Bumi Aksara. Jakarta.

Haryono. 2004. Komunitas Ikan Suku Cyprinidae di Perairan Sekitar Bukit Batikap Kawasan Pegunungan Muller Kalimantan Tengah. Jurnal Iktiologi Indonesia 4 (2) : $79-84$.

Kawaroe M. 2001. Kontribusi Ekosistem Mangrove Terhadap Struktur Komunitas Ikan di Pantai Utara Kabupaten Subang Jawa Barat. Jurnal Pesisir dan Lautan $3(3): 12-25$.

Kottelat M, Whitten AJ, Kartikasari SN, Wirjoatmodjo S. 1993. Freshwater Fishes of Western Indonesia and Sulawesi. Periplus Editions Limited. Jakarta. Ivii + 239 lrlm.

Mackinnon K, Hatta G dan Mangkalik A. 2000. Ekologi Kalimantan. Prenhallindo. Jakarta.

Ongki S, MS Anwari dan Herawatiningsih R. 2018. Keanekaragaman Jenis Ikan Air Tawar di Sungai Dong Sandar dan Sungai Rempangi Kecamatan Sungai Laur Kabupaten Ketapang. Jurnal Hutan Lestari 7 (1) : 21 31.

Puji F, Arief AP, Rofiza Y dan R Karno. 2017. Keanekaragaman Ikan (Pisces) di Danau Sipogas Kabupaten Rokan Hulu Provinsi Riau. Jurnal Biologi Udayana 21 (1) : $17-20$.

Rachmatika I dan Haryono. 1996. Ikhtiofauna di Taman Nasional Bentuang Karimun. Makalah 
Lokakarya "Keterpaduan Antara Konservasi dan Pembangunan Kawasan Taman Nasional Bentuang Karimun di Perbatasan Kalimantan Barat dan Malaysia". Pontianak, 13 - 14 november 1996.

Rahman A dan LW Khairoh. 2012. Penentuan Tingkat Pencemaran Sungai Desa Awang Bangkal Berdasarkan Nutrion Value Oeficient dengan menggunakan Ikan Nila (Oreochromis niloticus
Linn) Sebagai Bioindikator. Jurnal Ekosains 4 (1) : 1 - 10.

Sukmono T dan Margaretha M. 2017. Ikan Air Tawar di Ekosistem Bukit Tigapuluh. Yayasan Konservasi Ekosistem Hutan Sumatera dan Frankhurt Zoological Society.Jambi.

Titik TW dan A Zakaria. 2018. Keanekaragaman Ikan di Sungai Luk Ulo Kabupaten Kebumen. Jurnal Biosfera 35 (1) : 23 - 28. 